\title{
Anti blood group-M autoantibodies with livedo reticularis, Raynaud's phenomenon, and anaemia
}

\author{
J. M. SANGSTER ${ }^{1}$, M. G. KENWRIGHT ${ }^{1}$, M. P. WALKER ${ }^{2}$, AND \\ A. C. PEMBROKE ${ }^{3 *}$
}

From the ${ }^{1}$ Department of Haematology (Blood Group Serology and Blood Transfusion), the ${ }^{2}$ Department of Clinical Immunology, and the ${ }^{3}$ Department of Dermatology, The London Hospital, London E1, UK

SUMMARY A 63-year-old woman presented with Raynaud's phenomenon and extensive cold-induced livedo reticularis. A skin biopsy showed no abnormality of the blood vessels but the blood contained high titres of a very unusual autoantibody against the $\mathbf{M}$ blood group, most active at low temperatures. An IgM cryoglobulin was detected, and anti-M activity was found in this fraction. The cells of the patient were grouped as MM. The direct antiglobulin test was positive due to $C_{3}$ component of complement bound to the red cells. The haematological and biochemical results indicate a mild haemolytic process, which is at present well compensated.

Livedo reticularis may occur in a wide variety of diseases affecting the blood vessels of the skin or the rheological properties of the blood (Champion, 1965; Copeman, 1975). We describe the case of a woman with Raynaud's phenomenon and severe and extensive livedo reticularis regularly induced by cold and abolished by warmth, in whom the only abnormality found was an unusual anti-M autoantibody most active at low temperatures.

\section{Case history}

A 63-year-old housewife was admitted to The London Hospital in May 1977 complaining of purplish discoloration of the limbs. Ten months before admission she developed severe intermittent cramping pain in the upper arms, which was worse at night; this lasted for about three months and then resolved. At about the same time as the pain she noticed purple mottling especially of the hands but also of the arms and legs. This was worse in the cold and disappeared completely when she was very warm. For six months before admission she had noticed Raynaud's phenomenon affecting the hands. Prednisolone, $10 \mathrm{mg}$ daily, had been given for some weeks without benefit. She had had tuberculosis of the spine and rheumatic fever as a girl. She had had two miscarriages, and two live births with healthy infants. She had never had a blood transfusion. For some years before admission

*Present address: Department of Dermatology, King's College Hospital, Denmark Hill, London SE5

Received for publication 19 July 1978 she had been taking piperazine oestrone sulphate, $3 \mathrm{mg}$ daily, for postmenopausal flushing. On examination she was a little pale. When she was cool there was livedo reticularis over the arms and legs with no palpable nodules or ulceration. This disappeared when she was warm in a hospital bed. The peripheral pulses were normal and there were no other abnormal physical signs.

\section{INVESTIGATIONS}

Haemoglobin $9.5 \mathrm{~g} / \mathrm{dl}$, haematocrit 0.291 , mean corpuscular volume $92 \mathrm{fl}$, mean corpuscular haemoglobin $30.3 \mathrm{pg}$, mean corpuscular haemoglobin concentration $32.4 \mathrm{~g} / \mathrm{dl}$. Anisocytosis, polychromasia, and agglutination of the red cells were noted, but unfortunately a reticulocyte count was not performed. The blood count was repeated three months later in warm weather and showed a haemoglobin of 12.8 $\mathrm{g} / \mathrm{dl}$ and a reticulocyte count of $1 \cdot 2 \%$. The white cells and platelets were normal. Serum total bilirubin $28 \mu \mathrm{mol} / 1(1.6 \mathrm{mg} / 100 \mathrm{ml})$ direct $5 \mu \mathrm{mol} / 1(0.3 \mathrm{mg} /$ $100 \mathrm{ml})$, liver function tests otherwise normal. A biopsy of affected skin showed no abnormality on histological or immunofluorescent examination; the blood vessels were normal. The following were also normal or negative: antinuclear factor and autoantibody screen, latex fixation test, plasma protein electrophoresis, serum iron, vitamin $\mathbf{B}_{12}$ and folate, red-cell folate, urea and electrolytes, Treponema pallidum, haemagglutination, and VDRL slide test, microscopy and culture of the urine, and $x$-rays of the chest, skull, and hands. $X$-ray of the lumbar 
spine showed partial fusion of the fourth and fifth vertebrae but no sign of active tuberculosis.

\section{Special investigations}

\section{METHODS AND MATERIAL}

Phosphate buffered saline (PBS)

$0 \cdot 15 \mathrm{M}$ saline in Sörensen's phosphate buffer, $\mathrm{pH}$ range $6 \cdot 0$ to $8 \cdot 0$.

\section{Direct antiglobulin test (DAGT)}

$0.2 \mathrm{ml}$ of cells are washed four times in PBS pH 7.2 and tested against specific antihuman globulin IgG, anti $\mathrm{C} 3 / \mathrm{C} 3 \mathrm{c}$, anti-IgM, anti-IgA (Behring Werke AG) by the standard tile technique, and read after 5 minutes.

In the following testing procedures agglutination reactions were read microscopically at the appropriate temperatures of incubation $\left(4^{\circ} \mathrm{C}, 17^{\circ} \mathrm{C}, 30^{\circ} \mathrm{C}\right.$, and $37^{\circ} \mathrm{C}$ ) using the standard scoring system +++ , ,,,+++ \pm- .

\section{Saline reactions}

1 vol $3 \%$ suspension of cells in PBS pH $7 \cdot 2$ was mixed with 1 vol of serum and read microscopically after $1 \frac{1}{2}$ hours' incubation.

\section{Papain reactions}

1 vol of serum was mixed with $1 \mathrm{vol}$ of $5 \%$ suspension of papain-treated cells PBS pH 7.2 (Mollison, 1972), and agglutination was assessed macroscopically after one hour's incubation.

\section{Albumin displacement}

1 vol of serum was mixed with 1 vol of $3 \%$ cells in PBS pH $7 \cdot 2$ after $1 \frac{1}{2}$ hours, 1 vol of $20 \%$ serum albumin (30\% albumin diluted in AB serum to $20 \%)$ was added, and agglutination was read microscopically after a further 30 minutes' incubation.
Indirect antiglobulin test

Automatic Coombs washer (Spectra-Auto II) with AHG reagent incorporated in the cycle was used. $4 \mathrm{vol}$ serum $+1 \mathrm{vol} 20 \%$ suspension of cells in saline PBS pH 7.2 were incubated for one hour at $37^{\circ} \mathrm{C}$, before washing four times in the machine. After completion of the cycle the residuum was placed on a tile for macroscopic examination of agglutination and performance of the wash control.

\section{Titrations}

All sera were titrated by master-dilution technique using Pasteur pipettes and calibrated for the volumes required, with careful technique to avoid 'carry-over'. The agglutination was read microscopically.

\section{Cryoglobulin measurement}

This was carried out by the method of Weisman and Zvaifler (1975).

\section{Results}

The direct antiglobulin test was found to be weakly positive owing to the presence of complement $C_{3}$ bound to the red cells. A strong anti-M antibody was detected in the serum reacting over a wide thermal range of $4^{\circ} \mathrm{C}$ to $37^{\circ} \mathrm{C}$. Up to a temperature of $17^{\circ} \mathrm{C}$ the antibody reacted with $\mathrm{MM}, \mathrm{MN}$, and $\mathrm{NN}$ cells but only with $\mathrm{MM}$ and $\mathrm{MN}$ cells at $30^{\circ} \mathrm{C}$ and above, as shown in Table 1. It reacted with the patient's own cells at all temperatures, and the patient was typed as MM, giving negative results with several rabbit anti$\mathrm{N}$ sera and an extract of V:cia graminea.

Table 2 shows the titration results of the anti-M over a wide thermal range. Albumin addition techniques as well as saline were used, as cold agglutinin titres correlate better with the degree of haemolytic anaemia in the presence of bovine albumin than in saline (Garratty et al., 1977). Reactivity of the anti-M

Table 1 Specificity of the autoantibody over a wide thermal range

\begin{tabular}{|c|c|c|c|c|c|c|c|c|c|c|c|}
\hline & \multicolumn{2}{|c|}{$O$ Adult cells } & \multirow[b]{2}{*}{$M N$} & \multirow[b]{2}{*}{$M N$} & \multirow[b]{2}{*}{$M N$} & \multirow[b]{2}{*}{$N N$} & \multirow[b]{2}{*}{$M M$} & \multirow[b]{2}{*}{$M N$} & \multirow{2}{*}{$\begin{array}{l}\text { Own } \\
\text { cells }\end{array}$} & \multicolumn{2}{|c|}{$O$ cord } \\
\hline & $M M$ & $M M$ & & & & & & & & $M M$ & $N N$ \\
\hline $\begin{array}{l}4^{\circ} \mathrm{C} \text { Saline } \\
4^{\circ} \mathrm{C} \text { Papain } \\
17^{\circ} \mathrm{C} \text { Saline } \\
30^{\circ} \mathrm{C} \text { Saline } \\
30^{\circ} \mathrm{C} \text { Albumin } \\
37^{\circ} \mathrm{C} \text { Saline } \\
37^{\circ} \mathrm{C} \text { Albumin } \\
37^{\circ} \mathrm{C} \text { Papain } \\
37^{\circ} \mathrm{C} \text { IAGT }\end{array}$ & $\begin{array}{l}3+ \\
0 \\
3+ \\
3+ \\
3+ \\
1+ \\
3+ \\
0 \\
1+\end{array}$ & $\begin{array}{l}3+ \\
0 \\
3+ \\
3+ \\
3+ \\
1+ \\
2+ \\
0 \\
1+\end{array}$ & $\begin{array}{l}3+ \\
0 \\
2+ \\
2+ \\
2+ \\
1+ \\
2+ \\
0 \\
0\end{array}$ & $\begin{array}{l}3+ \\
0 \\
2+ \\
2+ \\
2+ \\
1+ \\
2+ \\
0 \\
0\end{array}$ & $\begin{array}{l}3+ \\
0 \\
2+ \\
2+ \\
2+ \\
1+ \\
2+ \\
0 \\
0\end{array}$ & $\begin{array}{l}3+ \\
0 \\
1 \\
0 \\
0 \\
0 \\
0 \\
0 \\
0\end{array}$ & $\begin{array}{l}3+ \\
0 \\
3+ \\
3+ \\
3+ \\
1+ \\
3+ \\
0 \\
1+\end{array}$ & $\begin{array}{l}3+ \\
0 \\
2+ \\
2+ \\
2+ \\
1+ \\
2+ \\
0 \\
0\end{array}$ & $\begin{array}{l}3+ \\
0 \\
3+ \\
3+ \\
3+ \\
1+ \\
3+ \\
0 \\
1+\end{array}$ & $\begin{array}{l}3+ \\
0 \\
3+ \\
3+ \\
3+ \\
1+ \\
2+ \\
0 \\
1+\end{array}$ & $\begin{array}{l}3+ \\
0 \\
1 \\
0 \\
0 \\
0 \\
0 \\
0 \\
0\end{array}$ \\
\hline
\end{tabular}

The antibody reacted equally with $0 \mathrm{MM}$ and $0 \mathrm{NN}$ cells at tempratures of $17^{\circ} \mathrm{C}$ and below but showed auto anti-M specificity at $30^{\circ} \mathrm{C}$ and above. Non reactivity with papain-premodified adult cells at $4^{\circ} \mathrm{C}$ excludes the presence of anti $\mathrm{I}$. 
Table 2 Titration results over a wide thermal range with adult, cord, and patient's own cells

\begin{tabular}{|c|c|c|c|c|c|c|c|c|}
\hline \multirow{3}{*}{$\begin{array}{l}\text { Temp. } \\
\left({ }^{\circ} \mathrm{C}\right)\end{array}$} & \multicolumn{8}{|c|}{ Titres with red cells } \\
\hline & \multicolumn{6}{|c|}{ Adult red cells } & \multicolumn{2}{|c|}{ Cord red cells } \\
\hline & O MM Sal & $O M M A l b$ & O MM Pap & o/c Sal & $o / c A l b$ & o/c Pap & O MM Sal & $O M M A l b$ \\
\hline 4 & 2000 & 2000 & 1 & 2000 & 2000 & 1 & 2000 & 2000 \\
\hline 17 & 1000 & 1000 & 1 & 2000 & 2000 & 1 & 1000 & 1000 \\
\hline 30 & 32 & 64 & 0 & 32 & 32 & 0 & 32 & 64 \\
\hline 37 & 1 & 8 & 0 & 1 & 4 & 0 & 0 & 8 \\
\hline
\end{tabular}

o/c = patient's own cells

Sal $=$ buffered saline $\mathbf{p H} \mathbf{7 \cdot 2}$

$\mathrm{Alb}=$ albumin-addition technique using $20 \%$ serum albumin

Cells and serum were pre-incubated at the appropriate temperatures before mixing.

These results show that the reactivity of the anti-M was enhanced by the use of albumin-addition at $37^{\circ} \mathrm{C}$.

Table 3 Anti-M activity tested at $30^{\circ} \mathrm{C}$ and $37^{\circ} \mathrm{C}$ at pH range $6 \cdot 0$ to $8 \cdot 0$

\begin{tabular}{llllll}
\hline Temp $\left({ }^{\circ} \mathrm{C}\right)$ & $p H$ Saline & \multicolumn{5}{l}{ Titres with adult red cells } \\
\cline { 3 - 6 } & & ONN & O MM & O MN & o/c \\
\hline 30 & $6 \cdot 0$ & 0 & 32 & 32 & 64 \\
& $7 \cdot 0$ & 0 & 32 & 16 & 32 \\
37 & $8 \cdot 0$ & 0 & 1 & 4 & 4 \\
& $6 \cdot 0$ & 0 & 32 & 32 & 32 \\
& $7 \cdot 0$ & 0 & 1 & 1 & 1 \\
& $8 \cdot 0$ & 0 & 0 & 0 & 0 \\
\hline
\end{tabular}

o/c = patient's own cells

The activity of the anti-M here shows characteristic pH dependence.

was increased at temperatures above $30^{\circ} \mathrm{C}$ in the presence of albumin.

The antibody showed typical dosage characteristics of anti-M, that is, variation in strengths of reaction with homozygous and heterozygous cells for the $M$ antigen. It was not active with papain-treated cells. At $30^{\circ} \mathrm{C}$ and $37^{\circ} \mathrm{C}$ its activity was $\mathrm{pH}$ dependent (Table 3).

\section{INVESTIGATION OF SERUM PROTEINS}

Serum immunoglobulins were assayed using the Mancini technique yielding the following results:

IgG $15 \cdot 28 \mathrm{~g} / 1$ (normal range $5 \cdot 00-15 \cdot 0 \mathrm{~g} / \mathrm{l}$ )

IgM $\quad 1 \cdot 25 \mathrm{~g} / \mathrm{l}$ (normal range $0 \cdot 60-1 \cdot 80 \mathrm{~g} / \mathrm{l}$ )

IgA $\quad 3.36 \mathrm{~g} / 1$ (normal range $0 \cdot 75-2 \cdot 50 \mathrm{~g} / \mathrm{l}$ ).

No paraprotein band was demonstrated on cellulose acetate electrophoresis, and no abnormal arcs were detected by immunoelectrophoresis. The serum used in these tests was collected and separated at $37^{\circ} \mathrm{C}$. All tests were performed at $37^{\circ} \mathrm{C}$. The serum cryoglobulin was $0.39 \mathrm{mg} / \mathrm{ml}$. The normal range in this laboratory is $0-0.15 \mathrm{mg} / \mathrm{ml}$

The washed cryoprecipitate was tested by the Mancini technique for IgG, IgM, IgA, and $\mathrm{C}_{3}$ and by Ouchterlony and immunoelectrophoresis for the presence of IgG, IgM, IgA, $\mathrm{C}_{3}$, and fibrinogen. The IgM level in the cryoprecipitate was estimated to be
$0.27 \mathrm{mg} / \mathrm{ml}$. No IgG, IgA, or $\mathrm{C}_{3}$ was detected. Both kappa and lambda chains were detected by Ouchterlony and immunoelectrophoresis, and the antihuman whole serum gave only one arc identifying with anti-human IgM serum.

The cryoprecipitate fraction prepared was tested against cells in PBS pH $7 \cdot 2$, which indicates that it possesses anti-blood group $M$ activity (Table 4).

It is intended to continue our investigations of the cryoglobulins and to look for the presence of immune complexes.

Table 4 Agglutination of cryoprecipitate fraction in PBS

\begin{tabular}{llll}
\hline & $O M M$ & $O N N$ & $O M N$ \\
\hline Saline $17^{\circ} \mathrm{C}$ & $3+$ & 0 & $2+$ \\
\hline
\end{tabular}

\section{Discussion}

Livedo reticularis is a physical sign seen wherever the flow of blood in the subpapillary venous plexus of the skin becomes so slow that the vessels dilate and fill with deoxygenated blood. This forms a bluish network. This slowing of blood in the subpapillary plexus is seen in healthy subjects in the cold and also in various diseases, as a result of either arterial damage or the presence of abnormal constituents of the blood, which either block the arteries or alter the flow properties of the blood passing through the capillaries and venules (Champion, 1965; Copeman, 1975). Slowing of blood in the small vessels of the conjunctivae is observed in patients with cold agglutinin disease when ice is applied, and flow returns to normal on warming (Iwai and Mei-Sai, 1925; Nelson and Marshall, 1953). Most patients with cold-agglutinin disease show Raynaud's phenomenon, cyanosis, livedo reticularis, and ischaemia of those parts of the body most exposed to the cold: the hands, nose ears, and toes (Ferriman et al., 1951; Dacie, 1962). Similar changes may be provoked on 
other parts of the body on cooling (Schubothe, 1966).

Although our patient's livedo reticularis was much more prominent in the cold and disappeared on thorough warming, it is not clear why she should have such extensive livedo reticularis. This could reflect the wide thermal range of her antibody, but it is more likely to be due to the association of her antibody with cryoglobulins, which can be associated with extensive livedo reticularis (Mackenzie et al., 1961).

Anti-M autoantibodies appear to be very rare. Bowes (1976) reported a case of a woman with Raynaud's phenomenon, anaemia, and anti-M autoantibody but did not mention whether cryoglobulins were present. Other examples of auto-anti$\mathbf{M}$ have been reported in the literature (Fletch and Zmijewski, 1970; Hysell et al., 1973; Tegoli et al., 1970) but the majority of cases did not show any similar clinical significance. Other blood group specificities have been implicated with cold-agglutinin disease; these are anti I, anti i (Issitt and Issitt, 1976), anti-Gd, and anti-Pr (Roelcke et al., 1976). These are rarely associated with cryoglobulins.

We have not treated our patient so far because her symptoms are relatively mild, but plasmapheresis and continuous-flow centrifugation (Taft $e t$ al., 1977) and chlorambucil treatment may have to be considered. There is no evidence of lymphoma or other malignant disease in this patient. However, Schubothe (1966) notes that there is a steady increase of lymphoid cells in the bone marrow of many patients with cold-agglutinin disease and suggests that it may represent a chronic lymphoprofilerative disorder.

We thank Professor G. C. Jenkins for his encouragement in writing this paper, and Dr. Harvey Baker for permission to publish the findings on his patient.

\section{References}

Bowes, A. (1976). Chronic cold agglutinin due to auto anti-M. Proceedings of the 8th Conference of the National Blood Transfusion Service, Session A.

Champion, R. H. (1965). Livedo reticularis. A review. British Journal of Dermatology 77, 167-179.

Copeman, P. W. M. (1975). Livedo reticularis. British Journal of Dermatology, 93, 519-529.

Dacie, J. V. (1962). The Haemolytic Anaemias Congenital and Acquired, 2nd edition, pt. 2, pp. 482-7. J. and A. Churchill, London.
Ferriman, D. G, Dacie, J. V., Keele, K. D., and Fullerton, J. M. (1951). The association of Raynaud's phenomena, chronic haemolytic anaemia, and the formation of cold antibodies. Quarterly Journal of Medicine, 20, 275-292.

Fletcher, J. L., and Zmijewski, C. M. (1970). The first example of auto-anti-M and its consequences in pregnancy. International Archives of Allergy and Applied Immunology, 37, 586-595.

Garratty, G., Petz, L. D., and Hoops, J. K. (1977). The correlation of cold agglutinin titrations in saline and albumin with haemolytic anaemia. British Journal of Haematology 35, 587-595.

Hysell, J. K., Beck, M. L., and Gray, J. M. (1973). Additional examples of cold autoagglutinins with $\mathbf{M}$ specificity. Transfusion, 13, 146-149. 2nd edition.

Issitt, P. D., and Issitt, C. H. (1976). Applied Blood Group Serology, pp. 302-311. Spectra Biologicals, Oxnard, California.

Iwai, S., and Mei-Sai, N. (1925). Etiology of Raynaud's disease. Japan Medical World, 5, 119-121.

McKenzie, A. W., Earle, J. H. O., Lockey, E., and Mitchell-Heggs, G. B. (1961). Essential cryglobulinaemia. British Journal of Dermatology, 73, 22.

Mollison, P. L. (1972). Blood Transfusion in Clinical Medicine, 5th edition, p. 402. Blackwell, Oxford.

Nelson, M. G., and Marshall, R. J. (1953). The syndrome of high-titre cold haemagglutination. British Medical Journal, 2, 314-317.

Roelcke, D. (1974). Cold agglutination. Antibodies and antigens. Clinical Immunology and Immunopathology, 2, 266-280.

Roelcke, D., Ebert, W., and Geisen, H. P. (1976). Anti-Pr ${ }^{3}$ : serological and immunochemical identification of a new anti-Pr subspecificity. Vox Sanguinis, 30, 122-133.

Roelcke, D., Riesen, W., Geisen, H. P., and Ebert, W. (1977). Serological identification of the new cold agglutinin specificity anti-Gd. Vox Sanguinis, 33, 304-306.

Schubothe, H. (1966). The cold hemagglutinin disease. Seminars in Hematology, 3, 27-47.

Taft, E. G., Propp, R. P., and Sullivan S. A. (1977). Plasma exchange for cold-agglutinin haemolytic anaemia. Transfusion, 17, 173-176..

Tegoli, J., Harris, J. P., Nichols, M. E., Marsh W. ,L., and Reid, M. E. (1970). Autologous anti-I and anti-M following liver transplant. Transfusion, 10, 133-136.

Weisman, M., and Zvaifler, N. (1975). Cryoglobulins in rheumatoid arthritis. Rheumatology, 6, 60-70.

Requests for reprints to: Miss J. M. Sangster, Department of Blood Transfusion Clinical Laboratory, The London Hospital, Whitechapel, London E1 1BB 